\title{
MERENJE PARAMETARA I TESTIRANJE PERFORMANSI MODELA OTN MREŽE
}

\author{
Miloš Krstić, \\ Marina Marjanović2, * \\ ${ }^{1}$ Vojska Srbije, \\ Beograd, Srbija \\ 2Univerzitet Singidunum, \\ Beograd, Srbija
}

Odgovorno lice:

Marina Marjanović

e-pošta:

mmarjanovic@singidunum.ac.rs
Rezime:

Savremen način života korisnicima pruža nove telekomunikacione servise i usluge, što uslovljava njihove konstantne zahteve prema telekomunikacionim provajderima da obezbede sve veće informacione kapacitete. Ovaj zahtev nameće pitanje kako obezbediti veće kapacitete i brzine prenosa u uslovima ograničenog propusnog opsega postojećih optičkih transportnih mreža? Rešenje je primena OTN tehnologije u transportnim mrežama, a performanse ove tehnologije sagledane su kroz merenja karakterističnih parametra na optičkoj mreži kao i na testiranju mogućnosti OTN platformi.

U ovom radu, prikazani su rezultati merenja uradjenih u kompaniji „IRITEL“ prilikom testiranja multiservisnih platformi baziranih na OTN/DWDM tehnologiji. Posebna pažnja data je na ugrađenom FEC mehanizmu koji obezbeđuje kvalitetan prenos siganala u uslovima velikog slabljenja, narušenog odnosa signal/šum ili izrazitog uticaja svih vrsta disperzija duž optičkog vlakna.

Ključne reči:

OTN/DWDM tehnologija, uređaj OTP10G IRITEL, merenje parametara (optičke snage, OSNR i disperzija) i testiranje performansi optičke transportne mreže.

\section{UVOD}

Povećanje brzine telekomunikacionog saobraćaja i povećanje kapaciteta prenosa stalni su zahtevi koji se postavljaju pred savremenim telekomunikacionim mrežama. Da bi se obezbedili ovi zahtevi potrebno je što efikasnije i fleksibilnije iskorišćenje postojećih resursa propusnog opsega i transportnih kapaciteta telekomunikacionih mreža.

Veoma brz razvoj telekomunikacija koji se desio krajem XX i početkom XXI veka rezultat je želja i potreba korisnika za pružanjem novih usluga i servisa sa malim kašnjenjem. Telekomunikacione mreže koje omogućavaju ove usluge, servise kao i dinamičko okruženje nazivaju se i širokopojasne mreže, a tehnologija prenosa naziva se "broadband" tehnologija.

Osnovni nosilac navedenog dinamičkog okruženja predstavljaju multiservisne optičke platforme. Multiservisne optičke platforme obezbeđuju bitske protoke do $10 \mathrm{Gbit} / \mathrm{s}$ po kanalu i kapacitete prenosa do 80 kanala, na rastojanjima koja prevazilaze nekoliko stotina kilometara, a uz to imaju i varijabilan propusni opseg u zavisnosti od potreba prenosa. 
Multiservisne optičke platforme bazirane na OTN (Optical Transport Network) i DWDM ( Dense Wavelength Division Multiplexing) tehnologiji obezbeđuju proširenje i nadogradnju postojećih optičkih transportnih mreža, baziranih na SDH (Synchronous Digital Hierarchy) tehnologiji, bez potrebe za infrastrukturnim ulaganjima koja se odnose na postavljanje novih optičkih kablova, jer je takva invensticija neekonomična sa gledišta telekomunikacionog provajdera.

U delu I ovog rada opisane su pojave degradacije signala pri velikim brzinama prenosa. U delu II, opisane su DWDM tehnologije, u delu III opisane su transportne mreže bazirane na OTN tehnologiji. Deo IV opisuje Multiservisnu platformu OTP10G IRITEL. U delu V, prikazani su rezultati merenja kao što su: merenje parametara i testiranje performansi OTN mreže, merenje optičke snage na trasi, raspodela OSNR duž optičke trase. Takodje, prikazana su merenja bitskih grešaka pri pojavama potkompenzacije/prekompenzacije uticaja hromatske disperzije.

\section{POJAVE DEGRADACIJE SIGNALA PRI VELIKIM BRZINAMA PRENOSA}

Osnovna komponenta svake optičke transporte mreže je optičko vlakno. Sa stanovišta prenosa kapaciteta njegove teoretske mogućnosti su beskonačne. Međutim povećanje kapaciteta uslovljava i povećanje brzine prenosa, ali povećanje brzine prenosa praćeno je pojavom degradacije signala usled nelinearnih efekata i intenzivnog uticaja disperzije, kako hromatske (CD) tako i disperzije polarizacionih modova (PMD) duž optičkog vlakna.

Ovi efekti degradacije signala su naročito izraženi pri brzinama prenosa većim od 2,5 Gbit/s i imaju kompleksne međusobne interakcije, a samim time i posledice koje se ne mogu zanemariti, jer direktno utiču na brzine prenosa i razdaljine na kojima se signal može preneti.

Efekat četvorotalasnog mešanja je nelinearna pojava koja takođe ima izrazit uticaj na prenos velikih protoka kroz optička vlakna. Ovaj efekat ograničava kapacitete kanala u optičkim transportnim sistemima i on se ne može ukloniti ni električnim ni optičkim filtrima, a raste sa porastom dužine optičkog vlakna.

U prenosu signala sa protokom od $10 \mathrm{Gbit} / \mathrm{s}$ disperzija je važan ograničavajući faktor, često strožiji i od slabljenja. Hromatska disperzija može se predvideti i teoretski proračunati, a njen uticaj se može kompenzovati dodavanjem jedinica za kompenzaciju (DCM) na liniji.
Za razliku od hromatske disperzije, disperzija polarizacionih modova (PMD) je nepredvidiva, jer je statističke prirode, promenljivog je karaktera i vezana je za uslove sredine (npr. temperaturu, vibracije, naprezanje i razne vrste opterećenja) u kojoj se nalazi optičko vlakno, tako da može da dostigne velike vrednosti koje se ne mogu kompenzovati. Kada je na optičkoj linji izrazito velika PMD, telekomunikacioni provajderi imaju dve mogućnosti ili da ne koriste to optičko vlakno ili da ga jednostavno zamene, što često nije ekonomski isplatljivo.

\section{DWDM TEHNOLOGIJA}

Ključ napredka u pogledu prenosa velikih kapaciteta i brzina u optičkim transportnim mrežama donela je WDM tehnologija koja je omogućila da se u isto vreme više različitih optičkih signala na različitim talasnim dužinama prenose preko jednog optičkog vlakna, tako da više nije bilo potreba za menjanjem postojeće infrastrukture optičkih vlakana.

Multipleksiranje talasnih dužina WDM (Wavelength Division Multiplexing) predstavlja tehnologiju koja omogućuje da se $\mathrm{u}$ isto vreme više različitih optičkih signala na različitim talasnim dužinama prenose preko jednog optičkog vlakna. Svaki od signala koji se prenosi u WDM sistemu može biti sinhroni/asinhroni digitalni signal ili analogni signal, koji se može prenositi nezavisno od ostalih signala, bez obzira na njegovu strukturu. Princip multipleksiranja talasnih dužina u WDM sistemima ilustrovan je na slici 1 .

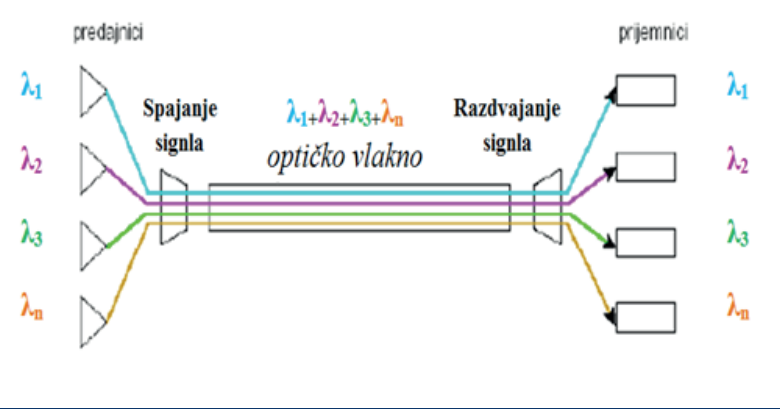

Slika 1. Princip multipleksiranja talasnih dužina

Unapređenje ove tehnologije doneli su DWDM sistemi kojima je obezbeđena potpuna transparentnost $u$ pogledu različitih brzina i formata signala koji se prenose, a zahvaljujući pre svega čisto optičkim funkcijama osnovnih komponenti ovog sistema. 


\section{TRANSPORTNE MREŽE BAZIRANE NA OTN TEHNOLOGIJI}

Danas je OTN dominantna tehnologija u transportnim optičkim mrežama u kojima se vrši prenos signala velikog bitskog protoka kroz optičke mreže bazirane na DWDM. OTN tehnologija je definisana ITU-T G.872 preporukom ${ }^{[1]}$ koja propisuje njenu arhitekturu, dok su struktura rama i multipleksiranje SDH, Ethernet i drugih signala definisani prema ITU-T G.709/Y.1331 preporuci. ${ }^{[2]}$ Drugim rečima OTN tehnologija obezbeđuje standardni protokol nove generacije koji omogućava efikasan i prihvatljiv način multipleksiranja različitih servisa u signal koji je prilagođen transparentnom prenosu kroz optički spojni put.

OTN tehnologiju karakteriše prilagođenost WDM mrežama, čime se postiže povećanje ukupnog kapaciteta linka, dok se povećanje dometa postiže korišćenjem zaštitnih kodova sa mogućnošću ispravljanja grešaka FEC (Forward Error Correction) mehanizma. Pozitivne karakteristike OTN tehnologije je i skalabilnost (osnovna granularnost od $1.25 \mathrm{Gbit} / \mathrm{s}$ ) i transparentni prenos klijentskih signala, uključujući i transparetni prenos $\mathrm{SDH}$ signala sa očuvanim transportnim zaglavljem. Pored agregacije postojećeg SDH saobraćaja OTN platforma omogućava i prenos Ethernet paketskog saobraćaja u optičkom domenu.

Glavni ciljevi koji se postižu primenom OTN/ DWDM tehnologije u transportnim platformama su kvalitet i pouzdanost (pružanje zahtevanog visokog nivoa servisa), skalabilnost (obezbeđivanje fleksibilnosti kapaciteta prenosa), prilagodljivost (razvijanje novih servisa, a da se pri tome ne ugrozi pružanje i kvalitet postojećih servisa) i upravljivost (obezbeđenje jedinstvenog funkcionisanja servisa i aplikacija, čime se telekomunikacionom provajderu omogućava efikasno upravljanje mrežom).

\section{MULTISERVISNA PLATFORMA OTP10G IRITEL}

OTP10G kompanije „IRITEL“ iz Beograda, predstavlja multiservisnu optičku transportnu platformu zasnovanu na OTN/DWDM tehnologiji, koja omogućava transport, mapiranje i multipleksiranje svih tipova korisničkih signala od $100 \mathrm{Mbit} / \mathrm{s}$ do $10 \mathrm{Gbit} / \mathrm{s}$ u jedinstveni linijski signal za prenos po optičkim vlaknima. Platforma podržava mapiranje i prenos: OTN, SDH, NG-SDH (Next Generation SDH), Ethernet (FE, GbE, 10GbE), SAN (Storage Area Network) i CBR (Constant Bit Rate) klijentskih signala. ${ }^{[3]}$
Platforma podržava DWDM optičko multipleksiranje saobraćaja po talasnim dužinama, odnosno prenos do 80 optičkih kanala po jednom paru optičkih vlakana sa mogućnošću odgranjavanja/dodavanja u čvorovima mreže. Ugrađeni optički pojačavači omogućavaju povećanje maksimalne dužine optičkih deonica, a time i ukupnog dometa. Funkcionalnost platfome ogleda se u spajanju OTN, standarne SDH, NG-SDH i Ethernet tehnologije u jedinstveni uređaj OTP10G koji je prikazan na slici 2.

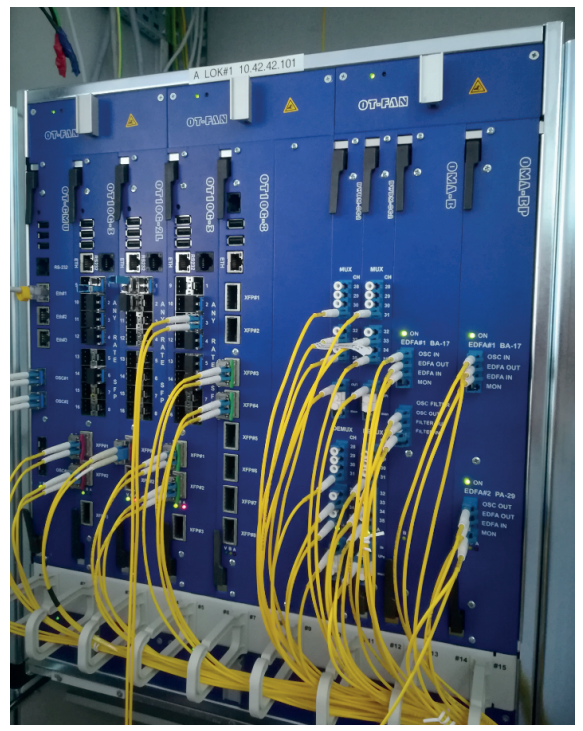

Slika 2. Uređaj OTP10G u radu

Osnovne jedinice uređaja OTP10G su:

- Kontrolno upravljačka jedinica OT-CMU, namenjena je za monitoring svih alarma, konfigurisanje sistema, kontrolisanje softvera, nadzor performansi OTN i DWDM modula i nadgledanje sistema.

- Transponderska i muksponderska jedinica OT10G, ima funkcije transpondera, mukspondera, prospajanja i zaštite saobraćaja. Ona obezbeđuje veliki broj linijskih i klijenskih interfejsa različitih brzina i protokola. Protokoli na svim interfejsima su OTN, SDH, Ethernet i bit transparentni protokoli.

- 10G XFP optički primopredajnici - moduli, podržavaju sve bitske brzine od 9,95 do 11,3 Gbit/s.

- Optičke EDFA pojačavačke jedinice OMA, koje služe za pojačanje optičkog DWDM signala, a u zavisnosti od tipa pojačavača. 
- DWDM-8C2 - jedinica za de/multipleksiranje optičkih signala po talasnim dužinama.

- DCM-DxDy - jedinica za kompenzaciju hromatske disperzije, koje eliminišu uticaj hromatske disperzije na optičkim vlaknima na daljinama od $20,40,60,80,100$ i $120 \mathrm{~km}$.

Upravljanje i nadzor uređaja OTP10G u OTN mrežama vrši se softverom "SUNCE + modul za OTN", koji omogućava i praćenje ispravnosti rada mreže, kvaliteta i pouzdanosti servisa, kao i promenu kapaciteta mreže.

\section{MERENJE PARAMETARA I TESTIRANJE PERFORMANSI MODELA OTN MREŽE}

Sagledavanje uticaja negativnih faktora koji se javljaju pri prenosu signala velikih bitskih brzina kroz optičko vlakno i principi delovanja ugrađenih mehanizama kojima se eliminišu uticaji navedenih faktora, glavni je cilj ovih merenja.

Performanse mreže su sagledane kroz merenja vrednosti optičke snage i OSNR u referentnim tačkama na trasi (na izlazu primopredajnika, na izlazu MUX/ DMUX, na izlazima pojačavača i na ulazu u prijemnik) u uslovima pojave veštački izazvanog slabljenja ili pojave disperzije. Poseban akcenat je dat na praćenju rada FEC mehanizma i njegovoj sposobnosti da omogući kvalitetan prenos signala u uslovima velikog slabljenja, narušenog OSNR ili izrazitog uticaja svih vrsta disperzija na optičkom vlaknu.

Realizovana su merenja optičke snage i OSNR duž optičke trase, merenja bitske greške (BER) pri prenosu SDH i Ethernet signala kroz optičku trasu sa i bez primene FEC mehanizma, merenja minimalnih vrednosti optičke snage i OSNR pri kojima je moguć prenos signala na optičkoj trasi, merenja vrednosti "džitera" pri prenosu SDH signala kroz OTN mreže i testiranje sistema pri pojavi potkompenzacije i prekompenzacije hromatske disperzije.

Za merenje i prikaz performansi korišćen je model optičke transportne mreže sa uređajima OTP10G kompanije „IRITEL“ baziranim na OTN/DWDM tehnologiji. Optička trasa (A-B-C-D) se sastoji od tri optičke deonice: prva deonica $\mathrm{A}-\mathrm{B}$ dužine $60 \mathrm{~km}$, druga deonica B-C dužine $100 \mathrm{~km}$ i treća deonica C-D dužine $100 \mathrm{~km}$. Ukupna dužina optičke trase u predajnom smeru je 260 $\mathrm{km}$, a takođe tolika je i dužina drugog para optičkih vlakana u prijemnom smeru. Blok šema optičke trase na kojoj su izvršena merenja data je na slici 3.

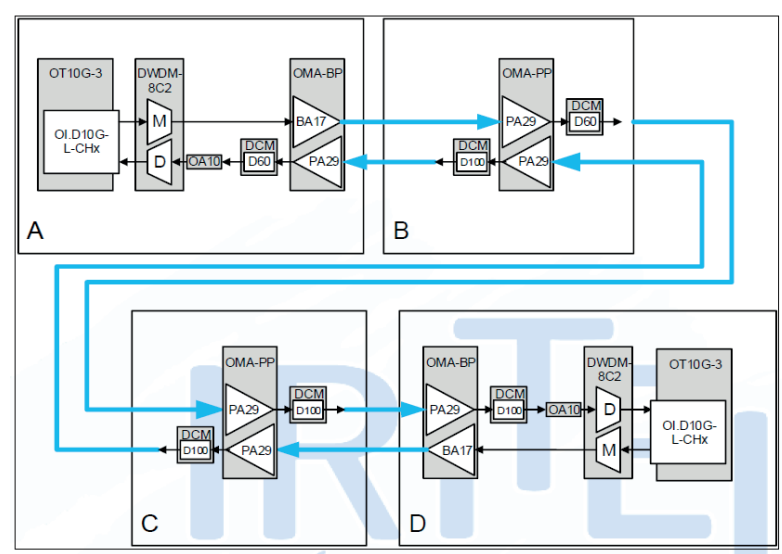

Slika 3 Blok šema modela optičke trase

Klijentski SDH (STM-4 i STM-16) i Ethernet (FE $i G E$ ) signali dovode se na odgovarajuće SFP module odnosno na ulaze prvog uređaja OTP10G, a pomoću softvera "SUNCE+" vrši se mapiranje pritočnih signala i to STM-4 i FE u ODU0 strukturu, STM-16 u ODU1 strukturu i GE u ODU2e strukturu. Nakon izvršenog mapiranja STM-4/16 i FE signala i dodavanja odgovarajućih zaglavlja formira se 32-gi optički kanal (na talasnoj dužini $1551,72 \mathrm{~nm}$ i frekvenciji 193,20 GHz) i 35-ti optički kanal sa mapiranim GE signalom (na talasnoj dužini 1549,32 nm i frekvenciji 193,50 GHz).

Preko XFP modula OI.D10G-L-CHx prvog uređaja ova dva kanala se vode na ulaze jedinice za multipleksiranje DWDM-8C2, gde se multileksiraju u jedinstveni linijski DWDM signal koji se vodi na prvi optički pojačavač BA-17, gde se signal pojačava (lokacija A na trasi), a zatim se šalje na prvu optičku deonicu dužine $60 \mathrm{~km}$.

Na kraju prve optičke deonice (lokacija B na trasi) nalazi se prvi predpojačavač PA-29 gde se signal pojačava i preko jedinice za kompenzaciju hromatske jedinice DCM60, vodi se na drugu optičku deonicu dužine 100 $\mathrm{km}$. Na njenom kraju (lokacija C na trasi) nalazi se drugi predpojačavač PA-29 gde se ponovo pojačava oslabljen optički signal i vrši se ponovo kompenzacija jedinicom DCM100, a zatim se signal vodi na treću optičku deonicu dužine $100 \mathrm{~km}$.

Na kraju treće optičke deonice (lokacija D trase) nalazi se treći optički predpojačavač PA-29 i preko jedinice za kompenzaciju hromatske disperzije DCM100 signal se preko optičkog atenuatora vodi na jedinicu za demultipleksiranje DWDM8C2 gde se vrši ponovno razdvajanje 32-og i 35-og kanala, a zatim se oba kanala vode na prijemnike odnosno XFP module. 
Isti postupak obrade signala vrši se i u smeru od lokacije D, preko lokacija C i B do lokacije A po drugom paru optičkih vlakana takođe dužine $260 \mathrm{~km}$. U modelu optičke trase korišćeno je optičko vlakno tipa G.652D ${ }^{[4]}$, a elementi optičke trase dati su na slici 4.

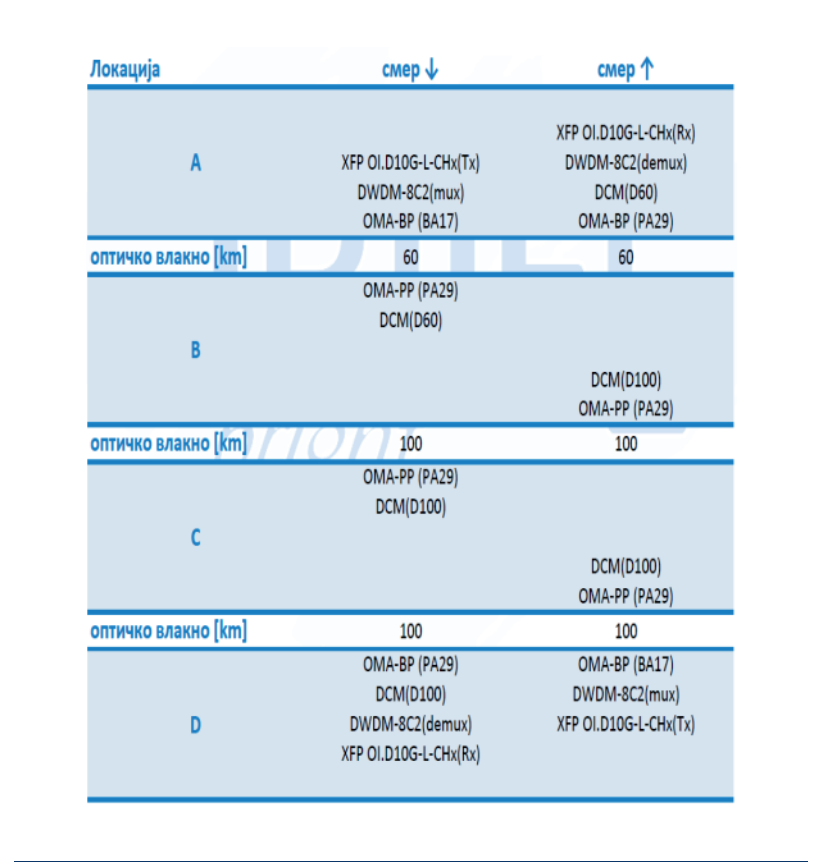

Slika 4. Elementi optičke trase

\section{Merenje optičke snage}

Cilj merenja je izmeriti optičku snagu signala u referentnim tačkama na trasi i to: na izlazu iz XFP modula prvog uređaja $\left(\mathrm{T}_{\mathrm{x}}\right)$, na ulazu/izlazu pojačavača BA-17 ( $\mathrm{A}_{\text {in }}$ / $\mathrm{A}_{\text {out }}$ ), na ulazu/izlazu svakog predpojačavača PA-29 na trasi $\left(\mathrm{B}_{\text {in }} / \mathrm{B}_{\text {out }}, \mathrm{C}_{\text {in }} / \mathrm{C}_{\text {out }}, \mathrm{D}_{\text {in }} / \mathrm{D}_{\text {out }}\right)$ i na ulazu XFP prijemnika drugog uređaja $\left(\mathrm{R}_{\mathrm{x}}\right)$. Merenja se vrše pomoću softvera „SUNCE+“, a izmerene vrednosti su predstavljne na dijagramu raspodele optičke snage na trasi A-B-C-D slika 5.

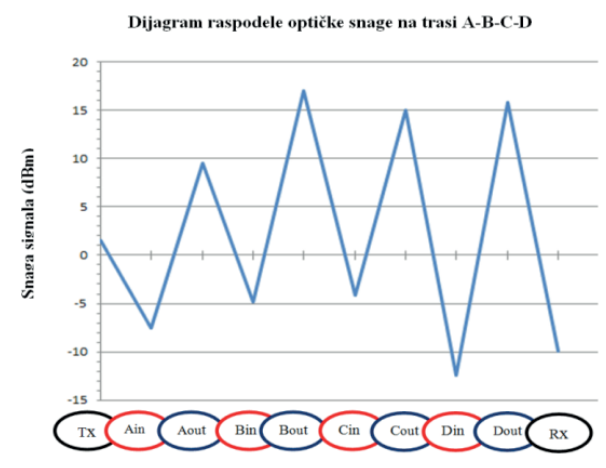

Slika 5. Dijagram raspodele optičke snage
Izmerena snaga na prijemu oba kanala u referentnoj tački $\left(\mathrm{R}_{\mathrm{x}}\right)$ iznosi -10,73 dBm odnosno -9,24 dBm, što odgovara propisanom tehničkom zahtevu od strane kompanije „IRITEL“ (u rasponu od $-7 \mathrm{dBm}$ do $-22 \mathrm{dBm}$ ).

\section{Raspodela OSNR duž optičke trase}

Cilj merenja je izmeriti odnos signal/šum (OSNR) u referentnim tačkama na trasi i to: na izlazu iz MUX i pojačavač BA-17 prvog uređaja, na izlazu svakog od 3 predpojačavača PA-29 na trasi i na izlazu iz DMUX drugog uređaja.

Merenja se vrše pomoću optičkog spektralnog analizatora EXFO FTB-500. ${ }^{[5]}$ Izmerene vrednosti predstavljene su na dijagramu raspodele OSNR na trasi A-D slika 6.

\section{Dijagram OSNR na trasi A-D}

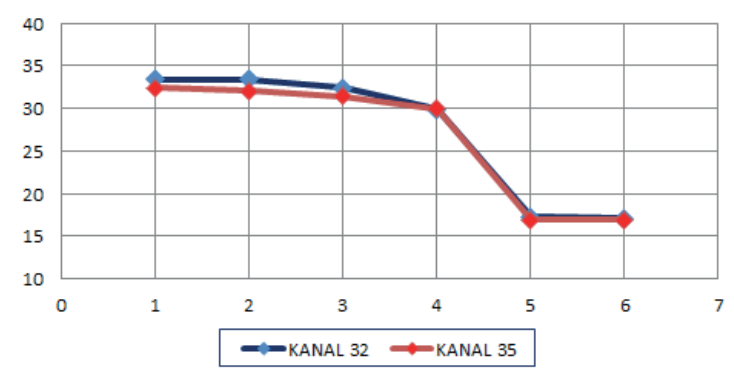

Slika 6. Dijagram OSNR na trasi

Izmerene vrednosti OSNR oba kanala u tački 6 (DMUX) iznose 17,10 dBm odnosno 16,92 dBm, što odgovara propisanom tehničkom zahtevu IRITELA da iste budu veće od $16 \mathrm{dBm}$.

Analizirajući dobijene vrednosti OSNR za svaki kanal i posmatrajući dijagram možemo videti kako vrednost OSNR opada sa povećanjem dužine optičke trase. Smanjenje OSNR duž linka do njegove minimalne vrednosti koju mogu da podnesu prijemnici, određuju minimalnu početnu snagu koju mora da ima svaki kanal da bi se garantovale određene performanse sistema.

Testiranje graničnih vrednosti optičkih pojačavača na trasi

Cilj testiranja je utvrditi minimalne granične vrednosti signala pri kojima će sistem funkcionisati i pri kojima će biti očuvan zahtevan nivo OSNR. 
$\mathrm{Na}$ ulaz svakog predpojačavača PA-29 dovodi se optički signal, a pomoću ateunatora vrši se slabljenje snage signala (čime se veštački simulira pojava velikog slabljenja na optičkoj trasi). Ovim se obezbeđuje da na svim ulazima predpojačavača PA-29 snaga bude približno $-27 \mathrm{~dB}$, što predstavlja graničnu vrednost rada ovih pojačavača, odnosno pojačavač ne može da vrši svoju funkciju zbog velikog slabljenja ulaznog signala.

Merenje izlazne optičke snage signala na sva tri predpojačavača PA-29, vršimo pomoću softvera „SUN$\mathrm{CE}+$ “. Navedenim softverom vršimo dodavanje ili oduzimanje određenog nivoa slabljenja na ulaze u predpojačavače PA-29, a na instrumentu EXFO FTB-500 posmatramo nivo odnosa signal/šum (OSNR) za svaki kanal posebno.

Uz približno isti nivo izlazne snage signala iz sva tri predpojačavača $(5,30 / 5,34 / 5,42 \mathrm{dBm})$ obezbeđuje se da odnos signal/šum (OSNR) po svakom kanalu (32-om i 35-om) na celoj optičkoj trasi bude veći od $16 \mathrm{dBm}$, što predstavlja graničnu vrednost OSNR i tehnički zahtev u IRITEL-ovim optičkim sistemima, a izmerene vrednosti date su u tabeli 1.

Tabela 1. Izmerene vrednosti izlazne snage i osnr

\begin{tabular}{|c|c|c|c|c|c|c|}
\hline \multirow{2}{*}{$\begin{array}{l}\text { Pojačavači } \\
\text { PA-29 } \\
\text { (deonica) }\end{array}$} & \multirow{2}{*}{$\begin{array}{c}\text { Ulazna } \\
\text { snaga } \\
\text { signala } \\
(\mathrm{dBm})\end{array}$} & \multirow{2}{*}{$\begin{array}{c}\text { Slabljenje } \\
\text { atenuatora } \\
\text { (dB) }\end{array}$} & \multirow{2}{*}{$\begin{array}{l}\text { Ulazna } \\
\text { snaga } \\
\text { signala u } \\
\text { pojačavač } \\
\text { (dBm) }\end{array}$} & \multirow{2}{*}{$\begin{array}{c}\text { Izlazna } \\
\text { snaga signala } \\
\text { iz pojačavača } \\
(\mathrm{dBm})\end{array}$} & \multicolumn{2}{|c|}{$\begin{array}{c}\text { Izmerena } \\
\text { vrednost OSNR } \\
(d B m) \text { za }\end{array}$} \\
\hline & & & & & 32.kan. & 35.kan \\
\hline $\begin{array}{l}\text { I pojačavač } \\
\text { deonica A-B }\end{array}$ & $-17,54$ & 9,92 & $-27,46$ & 5,30 & 24,89 & 24,86 \\
\hline $\begin{array}{c}\text { pojačavač } \\
\text { deonica B-C }\end{array}$ & $-25,28$ & 1,59 & $-26,87$ & 5,34 & 17,10 & 16,92 \\
\hline $\begin{array}{l}\text { III pojačavač } \\
\text { deonica C-D }\end{array}$ & $-20,10$ & 7,03 & $-27,13$ & 5,42 & 17,24 & 16,88 \\
\hline
\end{tabular}

Merenje bitskih grešaka pri pojavama potkompenzacije i prekompenzacije hromatske disperzije

Ova merenja treba da pokažu princip delovanja ugrađenog FEC mehanizma u uređajima OTP10G, a koji obezbeđuje prenos kroz optičku trasu u slučajevima pojave potkompenzacije i prekompenzacije hromatske disperzije.

U funkcionisanju već opisanog modela optičke trase pomoću jedinica DCM vrši se kompenzacija uticaja hromatske disperzije na optički signal pri prenosu. U uređajim OTP10G su postavljenje ploče sa jedinicama za kompenzaciju i to DCM60 za kompenzaciju na deonici A-B, jedinica DCM100 za kompenzaciju na deonici B-C i jedinica DCM100 za kompenzaciju na deonici C-D. a) Uticaj podkompenzacije na pojavu bitskih grešaka

Podkompenzaciju (povećanje vrednosti hromatske disperzije) simuliramo tako što iz uređaja OTP10G izvlačimo ploču sa jedinicom DCM60, a na instrumentu FTB-500 posmatramo vrednosti bitskih grešaka. U ovom slučaju sistem nastavlja da funkcioniše i nema pojave bitskih grešaka pri prenosu GE signala i pored toga što je FEC mehanizam isključen. Funkcionisanje sistema bez pojave BER se objašnjava time da sam XFP primopredajnik OI.D10G-L-CHx svojim karakteristikama može da toleriše uticaj hromatske disperzije u opsegu od -500 do $1600 \mathrm{ps} / \mathrm{nm}$.

Nakon toga iz sistema se izvlači i ploča sa jedinicom DCM100 (dodatno se simulira povećanje uticaja hromatske dispezije). U ovom slučaju dolazi do povećanja bitske greške pri prenosu GE signala, što je prikazani na slici 7.

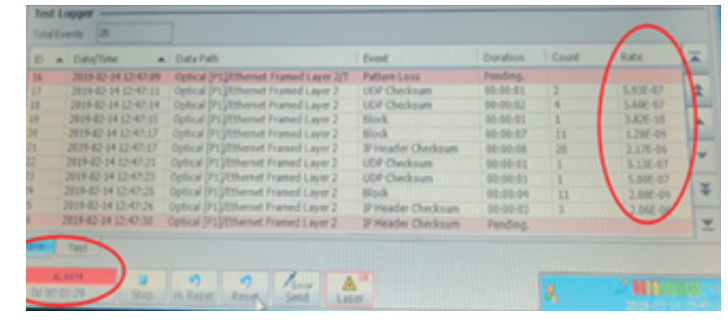

Slika 7. Pojava bitskih grešaka usled povećanja uticaja hromatske disperzije

Sama jedinica DCM100 vrši kompenzaciju hromatske disperzije u vrednosti oko $1700 \mathrm{ps} / \mathrm{nm}$. U sledećem koraku uključujemo FEC mehanizam i sistem nastavlja da radi bez pojave bitskih grešaka. Ovo pokazuje praktični doprinos ugrađenog FEC mehanizma u eleminaciji bitskih grešaka pri prenosu signala kroz optičke mreže.

\section{b) Uticaj prekompenzacije na pojavu bitskih greškaka}

Podrazumeva da se povećava broj jedinica za kompenzaciju hromatske disperzije u sistemu, što takođe kao i podkompenzacija može da utiče na pojavu bitskih grešaka pri prenosu GE signala.

U prvom koraku pored već postojeće jedinice DCM60 u uređaju OTP10G dodajemo još jednu ploču sa jedinicom DCM60 i posmatra se prenos GE signala bez uključenog FEC mehanizma. U ovoj situaciji javljaju se bitske greške u prenosu GE signala, slično kao što je već prikazano na slici 7. U drugom koraku uključujemo FEC mehanizam i sistem ponovo uspostavalja prenos GE signala bez bitskih grešaka. 
Merenje „džitera“ pri prenosu SDH signala kroz OTN mrežu

Ova merenja treba da pokažu mogućnosti OTN uređaja da umanje vrednosti izlaznog "džitera" pri prenosu STM-4 signala kroz OTN mrežu u odnosu na isti taj prenos kroz SDH mrežu.

$\mathrm{U}$ prvom koraku koristimo dva SDH uređaja OTS622 IRITEL (multiservisna platforma bazirana na SDH tehnologiji sa bitskim protokom na linijskoj strani od $622 \mathrm{Mbit} / \mathrm{s}$ ) ${ }^{[6]}$ povezana sa dva optička vlakna (jedno za predaju, drugo za prijem).

$\mathrm{Na}$ prvom uređaju OTS622 dovodimo klijentski STM-4 signal iz generatora SDH signala, a na drugom uređaju OTS622 postavljanjem "petlje” vraćamo STM4 signal po drugom optičkom vlaknu i instrumentom (ANRITSU MP-1590B Network Performance Tester) ${ }^{[7]}$ merimo vrednosti izlaznog "džitera" signala STM-4, kao što je prikazano na slici 8 .

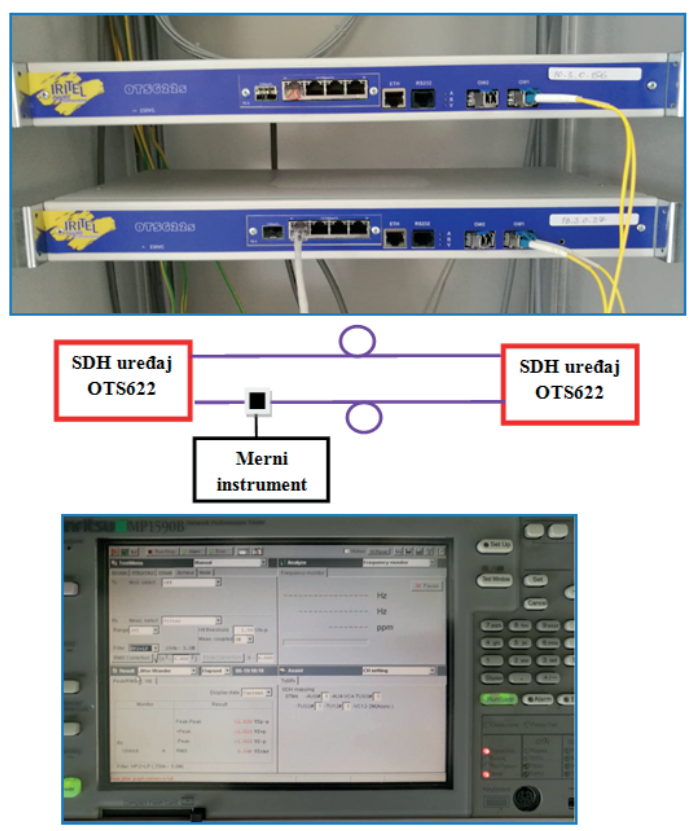

Slika 8. Merenje izlaznog “džitera” STM-4 pri prenosu kroz SDH mrežu

U drugom koraku STM-4 signal dovodimo najpre na prvi uređaj OTS622, a zatim njegov linijski signal uvodimo kao klijentski signal u prvi OTN uređaj. Po jednom paru optičkih vlakana dužine $260 \mathrm{~km}$ signal se vodi na drugi OTN uređaj, a sa njega na drugi uređaj OTS622, gde se ponovo zatvara "petlja” za STM-4 signal, koji se sad vraća u suprotnom smeru po drugom paru optičkih vlakana. Preko "splitera” povezujemo instrument MP1590B i merimo vrednosti izlaznog „džitera“, što je i prikazano na slici 9, a izmerene vrednosti date su u tabeli br. 2 .

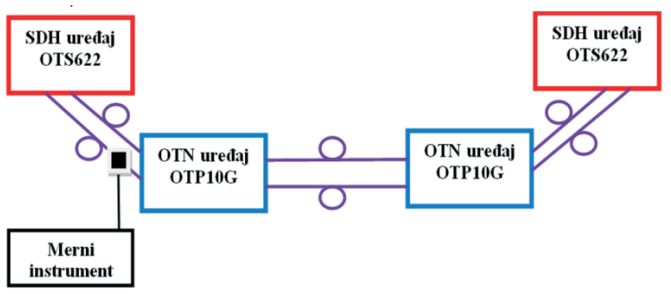

Slika 9 .Merenje džitera pri prenosu kroz OTN mrežu

Tabela 2. Izmerene vrednosti džitera pri prenosu stm-4

\begin{tabular}{|c|c|c|c|c|}
\hline Signal & $\begin{array}{l}\text { Primenjeni } \\
\text { FILTRI } \\
\text { (frek.opseg) }\end{array}$ & $\begin{array}{l}\text { Dozvoljena } \\
\text { vrednost } \\
\left.\text { džitera (UI } \text { (U) }_{p}\right) \\
\text { u frekventnom } \\
\text { opsegu }\end{array}$ & $\begin{array}{c}\text { Izmerene vrednosti } \\
\text { džitera (UI) u } \\
\text { frekv.opsegu pri prenosu } \\
\text { SDH-SDH }\end{array}$ & $\begin{array}{c}\text { Izmerene vrednosti } \\
\text { džitera (UI) u } \\
\text { frek.opsegu pri } \\
\text { prenosu } \\
\text { SDH-OTN-OTN-SDH }\end{array}$ \\
\hline \multirow{2}{*}{ STM4 } & $\begin{array}{c}\text { NP1-LP } \\
(1 \mathrm{KHz}-5 \mathrm{MHz})\end{array}$ & $1.5 \mathrm{UI}^{*}$ & $\begin{array}{l}\text { oppm } 0.364 \text { UI } \\
\left.\text { (pri }-10_{\mathrm{ppm}} \text { je } 0,319 \mathrm{UI}\right) \\
\left(\mathrm{pri}+10_{\mathrm{ppm}} \text { je } 0,313 \mathrm{UI}\right)\end{array}$ & $\begin{array}{l}\text { oppm } 0.006 \text { UI } \\
\left(\mathrm{pri}-10_{\mathrm{ppm}} \text { je } 0,05 \mathrm{UI}\right) \\
\left(\mathrm{pri}+10_{\mathrm{ppm}} \text { je } 0,06 \mathrm{UI}\right)\end{array}$ \\
\hline & $\underset{(250 \mathrm{KHz}-5 \mathrm{MHz})}{\text { NP2-LP }}$ & $0,15 \mathrm{UI}$ & $\begin{array}{l}\text { oppm } 0.02 \text { UI } \\
\left(\mathrm{pri}-10_{\mathrm{ppm}} \text { je } 0,023 \mathrm{UI}\right) \\
\left(\mathrm{pri}+10_{\mathrm{ppm}} \text { je } 0,025 \mathrm{UI}\right)\end{array}$ & $\begin{array}{l}\text { oppm } 0.001 \text { UI } \\
\text { (pri-10 } 10_{\text {pm }} \text { je } 0,02 \text { UI) } \\
\text { (pri+1 } 10_{\text {ppm. }} \text { je } 0,001 \text { UI) }\end{array}$ \\
\hline \multicolumn{5}{|c|}{ * Napomena: Prema ITU propisu G. 825 , za STM-4 1 UI = 1,61 ns } \\
\hline \multicolumn{5}{|c|}{$\begin{array}{l}\text { Izmerene vrednosti džitera pri prenosu kroz OTN mrežu su znatno niže }(0,006 \text { UI i } 0,001 \\
\text { UI) nego pri prenosu kroz SDH mrežu }(0,364 \text { UI i } 0,02 \text { UI), što potvrđuje izneti cilj na } \\
\text { početku ovog merenja. }\end{array}$} \\
\hline
\end{tabular}

\section{ZAKLJUČAK}

Svu superiornost OTN tehnologije mogli smo sagledati prilikom merenja i testiranja performasni na modelu optičke transportne mreže sa uređajima OTP10G, iz kojih smo mogli videti kako ugrađeni FEC mehanizam obezbeđuje zahtevani kvalitet prenosa u pogledu BERa i OSNR u uslovima povećanog slabljenja na trasi i u uslovima pojave hromatske disperzije. Takođe merenjem vrednosti „džitera“ mogli smo videti da je on značajno manji u OTN mrežama u odnosu na SDH mreže.

Integracija OTN/DWDN tehnologija u multiservisne optičke transportne platforme uz primenu čisto optičkih komponenti mreže (optičkih prekidača, „adddrop" multipleksera i "cross-conecta" na nivou talasnih dužina), uz primenu direktnih optičkih interfejsa i uz primenu novih servisa baziranih na QoS (stalni kvalitet usluga) omogućuje integraciju optičkih mreža različitih tehnologija u jednu tehničko-tehnološku celinu koja pruža transparentnost protoka i podržava primenu novih dinamičkih optičkih servisa. 
Dalji pravci razvoja mreža baziranih na OTN/ DWDM tehnologiji vode do sveoptičkih mreža (All Optical Network) u kojima se vrši prospajanje talasnih dužina GMPLS (Generalized MPLS) i koje se baziraju na komutaciji u fotonskom sloju. GMPLS vrši usmeravanje saobraćaja kroz optičku transportnu mrežu kreiranjem zajedničkog plana kontrole između IP-a i optičkog sloja, čime se obezbeđuje fleksibilna promena opsega u zavisnosti od potreba. Ove tehnologije neminovno će omogućiti prerastanje sadašnjih optičkih transportnih mreža u fotonske komunikacione mreže, odnosno mreže budućnosti.

\section{ZAHVALNOST}

Ističemo posebnu zahvalnost stručnim licima iz Sektora optičkih prenosnih sistema kompanije „IRITEL“ na pomoći i konstruktivnim savetima pri realizaciji merenja i testiranja performansi modela OTN mreže.

\section{LITERATURA}

[1] ITU-T Recommendation G.872, Architecture of optical transport networks, October 2012.

[2] ITU-T Recommendation G.709/Y.1331, Interfaces for the optical transport network, February 2012.

[3] IRITEL Beograd - "OTP10G - OTN/DWDM optička transportna platform 80x10 Gbit/s Tehnička dokumentacija 3.0, maj 2017.godine

[4] ITU-T Recommendation ITU-T G.652D, preuzeto sa internet strane https://www.itu.int/rec/T-RECG.975.1/en

[5] Preuzeto sa internet stranice: https://www.exfo. $\mathrm{com} /$ en/products/field-network-testing/modulartest-platforms/ftb-500/ dana 17.03.2019.g

[6] IRITEL Beograd - "ODS/OTS622TD-01- ver.2.04 Optički Digitalni sistem $622 \mathrm{Mbit} / \mathrm{s}$ ” - Tehnička dokumentacija jul 2007.godine

[7] Preuzeto sa internet stranice: https://dataedge.ie/ product/anritsu-mp1590b/ dana 17.03.2019.g 